\title{
Balls Casting Simulation and Practice FOR HADFIELD STELL
}

\author{
Marta, C.; Doroftei, I.; Prisacaru, G.; Hamat, C.; \\ SUCIU, L. \& ZGARDEA, E.
}

Abstract: Starting from the fact that the austenitic manganese steel casting (OAM) into ball shapes is difficult, as the pipe cavity is placed at the ball's surface or very close, we focused our research on the positioning of the casting defect into the ball's interior and as close as possible to the core. We performed simulations on the balls casting, and based on the simulation results we created the casting technology for 12-ball shapes, also presenting the practical results of the casting, which are almost identical to those of the simulation

Key words: austenitic, manganese, steel, casting, simulation
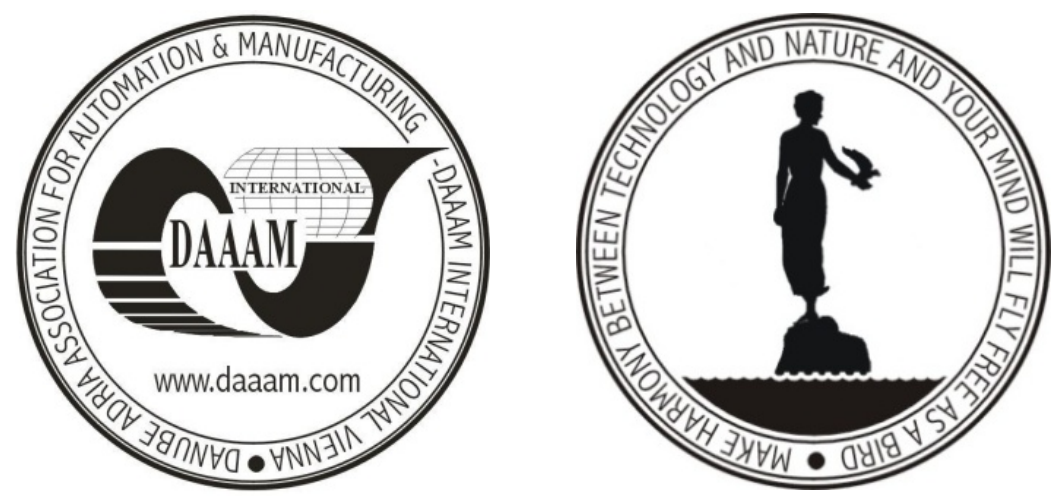

Authors' data: Prof. PhD Marta, C[onstantin]*; Prof. PhD Doroftei, I[oan]**; Prof. $\mathrm{PhD}$ Prisacaru G[heorghe]**; Prof. PhD, Hamat C[odruta]*; Lecturer PhD Suciu, L[enuta]*; Eng. Zgardea E[manuel]*, *University "Eftimie Murgu" Resita, Romania,**University Iasi, Romania, maco@uem.ro, ioan_doroftei@yahoo.com, prisacaru_ghe2004@yahoo.com, codruta.hamat@yahoo.com, ilesuciu@yahoo.com, emanuel@uem.ro

This Publication has to be referred as: Marta, C[onstantin]; Doroftei, I[oan]; Prisacaru, G[heorghe]; Hamat, C[odruta]; Suciu, L[enuta] \& Zgardea, E[manuel] (2009). Balls Casting Simulation and Practice for Hadfield Stell, Chapter 44 in DAAAM International Scientific Book 2009, pp. 427-442, B. Katalinic (Ed.), Published by DAAAM International, ISBN 978-3-901509-69-8, ISSN 1726-9687, Vienna, Austria

DOI:10.2507/daaam.scibook.2009.44 